\title{
Marian Mikołajczyk, Proces kryminalny $w$ miastach Małopolski XVI-XVIII wieku, Katowice 2013, ss. 620
}

DOI: http://dx.doi.org/10.12775/SIT.2015.013

Średniowieczne i wczesnonowożytne prawo procesowe stanowi istotną lukę $\mathrm{w}$ badaniach historycznoprawnych. Pomimo wielu cennych prac poświęconych tej tematyce, duża część zagadnień wymaga dalszego rozwinięcia oraz analizy w szerszym spektrum, zarówno terytorialnym, jak i czasowym. To samo dotyczy badań prawnoporównawczych modelu normatywnego, wynikającego $z$ regulacji prawnych, z praktyką sądową, gdyż ta, jak pokazują szczegółowe badania źródłowe, niejednokrotnie odbiegała od przepisów, a zatem wzorcowego schematu postępowania.

Marian Mikołajczyk od wielu lat $z$ powodzeniem bada różne aspekty dawnego prawa karnego materialnego i procesowego. Dotyczy to przebiegu postępowania, jego poszczególnych instytucji oraz innych pośrednio i bezpośrednio związanych $z$ procesem kwestii prawnych. Badania te uzupełniają analizy dla poszczególnych miast z egzemplifikacjami konkretnych spraw kryminalnych, prowadzonych przez sądy miejskie ${ }^{1}$. Najnowsza, licząca ponad 600 stron

${ }^{1}$ Zob. np. M. Mikołajczyk, Na drodze do powstania procesu mieszanego. Zmiany $w$ polskim procesie karnym $w$ latach 1764-1794, Katowice 1991; idem, Przestępstwo i kara $w$ prawie miast Polski południowej XVI-XVIII wieku, Katowice 1998; idem, Chłosta jako sposób wymuszania zeznań $w$ procesie karnym 
monografia Proces kryminalny $w$ miastach Małopolski XVI-XVIII wieku, wpisuje się w ten kierunek badawczy.

Mówiąc o „procesie kryminalnym”, a nie „procesie karnym”, autor odwołuje się do nowożytnego znaczenia tego terminu odróżniającego poważniejsze sprawy karne od pozostałych, drobniejszych, o odmiennym zgoła trybie postępowania (s. 16-17). W ten sposób temat został zawężony do zbrodni zagrożonych $\mathrm{z}$ reguły najwyższymi karami, z karą śmierci włącznie. Poza zainteresowaniem pozostają sprawy karne, ale nienoszące kryminalnego charakteru. Rozważania obejmują okres od XVI do XVIII wieku (1772). Dyktuje to $z$ jednej strony stan zachowania źródeł oraz powstanie licznych komentarzy prawnych, będących wyznacznikami dla praktyków do końca XVIII stulecia, a $z$ drugiej zmiany polityczne w związku $z$ wejściem Małopolski w orbitę wpływów austriackich, za którymi podążyły zmiany w postępowaniu sądowym. Bogaty materiał źródłowy pochodzi $z$ kilku krajowych ośrodków archiwalnych ${ }^{2}$. Odnosi się on do kilkunastu miast Małopolski. Oprócz największego - Krakowa, reprezentowane są również ośrodki mniejsze, m.in. Biecz, Dobczyce, Bochnia, Oświęcim, Tarnów i Żywiec. Uzupełnienie stanowią dzieła pióra poczytnych prawoznawców (Jana Tucholczyka, Jana Cerasinusa, Bartłomieja Groickiego, Pawła Szczerbica) oraz liczne wydawnictwa źródłowe (s. 578-583). Warto też odnotować szeroką gamę opracowań, do których autor sięgnął (s. 583-615),

miast polskich XVII-XVIII wieku, „Studia z Dziejów Państwa i Prawa Polskiego” 2002, t. 7; idem, Areszt tymczasowy $w$ prawie miejskim $w$ Polsce XVI-XVIII wieku, w: Współczesne problemy procesu karnego i wymiaru sprawiedliwości. Księga ku czci Profesora Kazimierza Marszała, red. P. Hofmański, K. Zgryzek, Katowice 2003; idem, Proces karny $w$ miastach polskich (XVI-XVII w.) -jedność czy wielość procedur?, „Zeszyty Prawnicze Uniwersytetu Kardynała Stefana Wyszyńskiego” 2011, t. 11; idem, „Iterrogatoria ante publicationem decreti”. Uroczyste potwierdzenie zeznań $w$ praktyce sadu miejskiego $w$ Grodzisku Wielkopolskim w I połowie XVIII wieku, w: Księga pamiątkowa poświęcona Profesor Krystynie Kamińskiej, red. A. Gaca, Torun 2013.

2 Archiwum Akt Dawnych w Warszawie, Archiwów Państwowych w Katowicach, Krakowie, Przemyślu, Tarnowie, Biblioteki Jagiellońskiej, Biblioteki Polskiej Akademii Umiejętności i Polskiej Akademii Nauk w Krakowie oraz Muzeum Okręgowego w Tarnowie. 
a uwzględniających zarówno starsze, jak i najnowsze wyniki i kierunki badań.

Praca została podzielona na 15 rozdziałów. Prawie każdy $z$ nich wieńczy syntetyczne podsumowanie. Znajdują się w nim najważniejsze konkluzje bądź ewentualne wątpliwości co do omawianych zagadnień. Mimo że układ treści odpowiada kolejnym etapom postępowania, to $\mathrm{z}$ uwagi na obszerność tematu, omawiając określone instytucje, autor dokonał pewnych przesunięć. Pozwoliło to uniknąć niepotrzebnych powtórzeń, a tym samym wpłynęło pozytywnie na sposób przedstawienia poszczególnych treści.

Pierwsze trzy rozdziały dotyczą spraw ogólnych: sądów orzekających w sprawach kryminalnych (rozdział I), właściwości sądowej (rzeczowa, osobowa, miejscowa; rozdział II) oraz uczestników postępowania (rozdział III). Mikołajczyk zauważa, że średniowieczny model organizacji sądownictwa i procedowania w sprawach kryminalnych nie utrzymał się w okresie nowożytnym (s. 58). W niektórych miastach osobno orzekała ława bądź rada (rzadziej), gdzie indziej przyjmowano model mieszany, w którym poszczególne organy łączono w jeden. Możliwe było również poszerzenie składu sądowego o reprezentacje cechową czy sądownictwa dominalnego, co nie było sytuacją wcale rzadką. To samo dotyczy właściwości. Mianowicie sądy miejskie wykraczały poza kompetencję miejscową i osobową, sądząc reprezentantów różnych stanów, nawet pochodzących spoza danej jurysdykcji. Był to przejaw zasady represji wszechświatowej, traktowanej jednak często w sposób nader wybiórczy.

Właściwy przebieg postępowania obejmuje: czynności przygotowawcze do procesu (rozdział IV), wszczęcie procesu (rozdział V), postępowanie dowodowe i stosowane w nim środki (rozdziały VI-XI), rozprawę (rozdział XII), wyrok (rozdział XIII), formy zaskarżania orzeczeń (rozdział XIV) i postępowanie wykonawcze (rozdział XV). Najmniej informacji dają źródła na temat działań podejmowanych przed rozpoczęciem postępowania. Co prawda, zapisy $z$ akt kryminalnych mówiły o wizjach, obdukcjach czy protestacjach, trudno natomiast uznać je za stały element procesu, a zatem wnioskować o jakichkolwiek utartych wzorcach (poza ujęciem na gorącym uczynku). O wiele więcej można powiedzieć o wszczęciu postępowania (o czym dalej) i kolejnych stadiach procesu. Obszerne uwagi autora dotyczą dowo- 
dów, z zasadami rządzącymi ich przeprowadzaniem. Rozpoczyna je kwestia dowodu $z$ dobrowolnych zeznań i tortur, po czym omówione zostały inne środki: zeznania świadków, przysięga dowodowa, dowód z dokumentów, oględziny, opinie biegłych, okazanie, a w sprawach dotyczących uprawiania czarów pławienie. Mikołajczyk konstatuje, że w zakresie dowodzenia małopolskie sądy wykazywały sporą elastyczność w korzystaniu $z$ różnych środków dowodowych. Poza podstawowymi w postaci zeznań oskarżonych i świadków, sięgano do innych, które mogły mieć znaczenie dla meritum sprawy (s. 416). Omawiając rozprawę sądową, autor wskazuje najpierw możliwości stawiania zarzutów (ekscepcji) oraz dylacji. O ile te pierwsze mogły całkowicie zniweczyć postępowanie bądź przynajmniej je odroczyć, to dylacje pełniły wyłącznie tę drugą funkcje. Brak zasadnych zarzutów formalnych i wniosków o odroczenie terminu pozwalało na merytoryczną rozprawę. Odrębnie ujętym problemem jest wydanie wyroku. Tak jak w przypadku wielu czynności, z którymi przepisy prawa oraz prawoznawcy wiązali odpowiedni rytuał (np. przysięgi dowodowej), trudno dziś stwierdzić, czy nadal go praktykowano (s. 508). W tym względzie źródła nie pozwalają na jasną odpowiedź. W zakresie sposobów zmiany orzeczenia warto podkreślić, że sądy małopolskie rzadko dopuszczały do rozpatrywania spraw przez sądy wyższej instancji. Podtrzymywano nadal, że od wyroków w postępowaniach kryminalnych dopuszczenie apelacji miało charakter wyjątkowy. $Z$ tego powodu większą rolę niż instytucje prawa odgrywały czynniki faktyczne: ,interwencje wpływowych osób, stanowisko powoda (oskarżyciela), okazywanie łaski przez właścicieli dóbr albo i sam sąd wyrokujący" (s. 531). Było to zresztą zjawisko spotykane nie tylko w miastach Małopolski.

Ostatni rozdział dotyczy wykonania wyroku. Autor skupia się na procesie wiodącym do egzekucji orzeczenia. Dla skazanych na karę główną był to przede wszystkim czas na duchowe przygotowanie się do śmierci (spowiedź, przyjęcie Komunii świętej), a także wydanie dyspozycji w związku z majątkiem (testament). Ze strony władz zdarzało się, że uzupełniano dokumentacje o zeznania kolejnych świadków, nieraz też samego skazanego. Osobno podejmowano działania mające przygotować warunki do egzekucji wyroku. Na mar- 
ginesie pojawiają się uwagi na temat wykonania kary pozbawienia wolności oraz innych, stosowanych w tym czasie sankcji.

Warto też podkreślić dwa ogólne wnioski zawarte w recenzowanej pracy, a mające wymiar ogólny. Mikołajczyk zauważa, że skarga prywatna w praktyce miejskiej długo stanowiła podstawowy sposób wszczęcia postępowania przy jednoczesnym stopniowym wzroście zasady publicznoprawnej (s. 217). Sprawy wszczynane z urzędu należały do zdecydowanej mniejszości, nie mającej w warunkach Małopolski większego znaczenia statystycznego. Pozwala to uznać, że zasada skargowości zachowała mocną pozycję w nowożytnym procesie kryminalnym, opierając się większym wpływom procesu inkwizycyjnego (s. 218). Nie oznacza to natomiast, że ten nie wywarł znaczenia w dotychczasowej procedurze. Tym niemniej jego instytucje widoczne były wyraźniej w późniejszych etapach postępowania. Można nawet postawić tezę, że doszło w tym względzie do wymieszania się elementów procesu skargowo-kontradyktoryjnego, aczkolwiek zgodzić się należy z autorem, który uznaje „proces kryminalny czasów wczesnonowożytnych za proces skargowo-kontradyktoryjny, wzbogacony jedynie o pewne nowoczesne pierwiastki o inkwizycyjnym rodowodzie" (s. 573). Inną sprawą jest problem jedności procesu miejskiego. Podobnie jak w wypadku prawa materialnego, tak samo w procedurze kryminalnej, lecz w stopniu o wiele głębszym, zauważalne są liczne lokalne oraz terytorialne odmienności (s. 566-567). Dotyczyły one zresztą różnych spraw, niekiedy niezwykle istotnych dla przebiegu postępowania. Zdaniem autora nie daje to jednak podstaw do twierdzeń o partykularnych systemach procedury. Wystarczające jest porównanie praktyki przykładowego dużego miasta (np. Krakowa) o ustalonej procedurze, gdzie na stanowiskach sądowych znajdowały się osoby reprezentujące określony poziom prawny, a mimo to w jego praktyce odnajdujemy wiele wyjątków, niekoniecznie zgodnych $z$ wcześniejszym, jak też późniejszym modelem postępowania. Zaryzykować więc można stwierdzenie o jedności procesu, przy jednoczesnym zauważaniu różnic charakterystycznych dla partykularyzmów.

To, co zwraca szczególną uwagę w monografii, to umiejętne łączenie problemów normatywnych z praktyką prawa. Szeroka 
kwerenda oraz pogłębione studia pozwoliły na liczne odwołania źródłowe, od których Mikołajczyk słusznie nie stroni, oraz stawianie bardziej ogólnych i dobrze uzasadnionych wniosków. Tym niemniej w kwestiach, w których materiał źródłowy budzi jakieś wątpliwości, są one jasno wyartykułowane, stanowiąc pole do dyskusji oraz jednocześnie wskazanie koniecznych do dalszych badań obszarów. Dodatkowo, $z$ uwagi na wykorzystanie materiału z różnych typów ośrodków, otrzymujemy analizę pełniejszą, uwzględniającą inne niekiedy punkty widzenia. Dotyczy to w szczególności mniejszych gmin, w których organach zasiadały osoby niebędące $z$ reguły profesjonalnymi prawnikami. Nie można jednak zapominać, że to właśnie małe oraz średnie miasta tworzyły główny pejzaż urbanistyczny Polski przedrozbiorowej, a zatem również i obraz prawa.

Reasumując, monografia Mariana Mikołajczyka stanowi ważny wkład w badania nad nowożytnym procesem. Wypełnia dotkliwą dotąd lukę, w szerszym ujęciu terytorialnym oraz czasowym. $Z$ całą pewnością wejdzie ona do kanonu tematu, znajdując zastosowanie nie tylko w badaniach historycznoprawnych, ale również pracach historyków, gdzie postępowanie sądowe lub jego źródła stanowią tło prowadzonych badań. Jest to także dobry punkt wyjścia dyskusji nad procesem w pozostałych częściach Korony, oczekujących dopiero na podobne, udane opracowanie. 